\title{
Plastic Tiles from Recycled Pet Bottles Wastes with Improved Strength and Reduced Flammability
}

\author{
Omosebi Taiwo. $\mathbf{O}^{1,2, *}$, Noor Faisal Abas ${ }^{1}$ \\ ${ }^{1}$ School of Housing Building and Planning, Universiti Sains Malaysia, Malaysia \\ ${ }^{2}$ Department of Building Technology, Federal Polytechnic Ado Ekiti, Ekiti State, Nigeria
}

Received April 29, 2021; Revised June 2, 2021; Accepted July 19, 2021

\begin{abstract}
Cite This Paper in the following Citation Styles
(a): [1], Omosebi Taiwo. O, Noor Faisal Abas, "Plastic Tiles from Recycled Pet Bottles Wastes with Improved Strength and Reduced Flammability," Civil Engineering and Architecture, Vol. 9, No. 5, pp. 1347 - 1355, 2021. DOI: 10.13189/cea.2021.090508.
\end{abstract}

(b): Omosebi Taiwo. O, Noor Faisal Abas (2021). Plastic Tiles from Recycled Pet Bottles Wastes with Improved Strength and Reduced Flammability. Civil Engineering and Architecture, 9(5), 1347 - 1355. DOI: 10.13189/cea.2021.090508.

Copyright $\odot 2021$ by authors, all rights reserved. Authors agree that this article remains permanently open access under the terms of the Creative Commons Attribution License 4.0 International License

\begin{abstract}
The cost of construction materials and the required natural resources to produce the materials with the enabling environment is affecting the world's construction industry which is growing at an alarming rate. Also, plastic wastes have posed a major threat to the environment due to their large usage, non-biodegradability nature, and pollution through incineration and landfill. Recycling these wastes into tiles will be a great advantage. This study aims at examining mechanical properties of tile made from PET (Polyethylene Terephthalate) wastes, fly ash, and river sand aggregate. The PET wastes of varying percentages of $100 \%, 90 \%, 70 \%, 50 \%$, and $30 \%$ by weight to other aggregates. The evaluation of physical and mechanical properties shows that, in terms of material density, strength, and flammability resistance, the tiles with $30 \%$ of the plastic waste yields better results than other proportions of the waste. According to the results obtained, this composite tile has a very low \% porosity value (2.8- $0.11 \%$ ) compared to cement or ceramic tiles. Also, the composite tile (PFST1) with $30 \%$ and $35 \%$ sand and fly ash displayed lower flammability of $7.76 \mathrm{~mm} / \mathrm{min}$ linear burning rate and enhanced compressive strength of $11.10 \mathrm{MPa}$. The chemical tolerance of these composite tiles was also investigated by soaking in different acid, base, and alkaline for seven days, which has no significant difference in terms of weight and appearance. In conclusion, PET plastic tiles have good strength, decrease flammability, low water absorption, and eco-friendliness as tiles products. This prospect would not only minimize the cost of building
\end{abstract}

products but will also act as a waste diversion to mitigate the environment caused by plastic waste disposal.

Keywords Polyethylene Terephthalate, Fly Ash, Compressive Strength, Porosity, Flammability

\section{Introduction}

Plastics have evolved into a necessary substance for daily use, with annual use gradually increasing over the last decades, owing primarily to inherited qualities such as low cost, simple-usable designs, manufacturing abilities, long-lasting, light in weight, and strength. Plastic garbage is one of wastes that are solidly created in a massive amount, posing a serious hazard to our planet's long-term viability [1]. Ecology, economy, and aesthetics have been reported to be affected when plastic debris reaches the oceans [2]. The estimated annual plastic waste produced is approximately 300 million metric tons [3]. Plastics were generated in 8.3 billion metric tons worldwide in 2017, with $80 \%$ of them being thrown in landfills or damaging the environment after usage $[4,5-6]$. Plastics are in common use due to their lightweight, soft nature, flexibility, non-corrosiveness, and durability. Plastics are comfortable packing materials and containers but wastes from plastics are a major cause of environmental pollution; they emit poisonous gases upon incineration and are not 
biodegradable. Plastic materials are reportedly carcinogenic as they contain chlorine and other carcinogens. The burning of plastic wastes produces toxic gases that are harmful to the environment. Since plastic wastes account for the highest percentage of waste produced globally, there is a need to ensure proper management of such waste. Plastics are commonly used as packing materials, but their wastes can be used in the construction industries to produce construction materials, such as floor tiles, roof tiles, building blocks, etc. This can reduce construction costs and minimize environmental pollution. For instance, plastic wastes can be mixed with sand and other additives to produce constructional materials [6]. Presently, recycled plastic wastes are gradually replacing natural materials such as fiber, metal, wood/timber, and sand, thereby preserving the natural environment. Proper management of solid wastes through recycling into new products will help to promote a sustainable environment, conservation of natural resources, and cheap raw materials $[1,7]$. On the other hand, the lack of adequate management of solid wastes will add to the existing environmental problem; hence, solid wastes must be properly managed by recycling them into new useful products $[8,9]$. Being that plastic wastes cannot decompose easily and are produced in huge quantities, depositing them into landfills may not be a permanent solution $[1-2,10]$.

Recycling is currently not an easy management strategy for plastic materials because it is a labor and capital-intensive process $[2,11]$. Previously, plastics were considered environmentally friendly materials that save energy, reduces raw material extraction, and fight climate change. However, the rate of plastic wastes generation has increased tremendously, and management has become a serious issue. Consequently, researchers have suggested the use of plastic wastes in concrete production for two major reasons; first, to resolve the environmental problem associated with their disposal; and second, to reduce construction costs since they are available in great quantities [9]. Cement is generally used as a binder in the construction industry; however, the high cost of cement has prevented many people from building their houses and has hindered the advancement of the construction sector [12-13]. Hence, it is important to find a suitable replacement for this expensive and essential building material $[14,15]$.

PET bottles are now used as binders in the manufacture of a wide range of building materials, including tiles. Shredded plastic waste is a recycled material that has gained lots of interest in the building industry [16]. Researchers have documented the potential suitability of plastic waste as building materials. Like, Mehdi et al. [17] reported that high-density polythene (HDPE) plastics can be used to make roof tiles when combined with sand. The results of their study revealed that composite tiles made with $70 \%$ HDPE had better performance and quality after analysis. Several experimental studies that used recycled PET bottles as a substitute for natural aggregates in concrete have recently been published [19], and as resin in polymer concrete [18]. Akinwumi et al. [19] documented the production of stabilized soil blocks from shredded plastic waste and their study opined that $1 \%$ finely shredded PET waste (size 6.3 microns) by weight could be used for successful block stabilization. Mustafa et al. [2019], looked into the possibility of PET waste as a fine aggregates substitute in the production of high-impact resistance building materials. The impact resistance increased by $39 \%$ in mortars made with a $20 \%$ plastic material. Kumi-Larbi et al. [20] reported a successful production of sand blocks using plastic waste and concluded that there is a possibility of producing durable and solid sand using only plastic waste without the use of additional water. Yang et al. [21] have also investigated the feasibility of producing eco-friendly door panels by combining plastic waste with wood dust. In a particular study, [22] used shredded PET waste to make roof tiles and discovered that as the PET volume decreased, the compressive strength increased. Borg et al. [23] used PET fibers in concrete and discovered that at higher PET fiber contents, PET fibers significantly reduced compressive strength of the sample. Al-Hadithi and Hilal [22] investigated the use of recycled plastic fibers in the production of self-compacting concrete and discovered that as the plastic waste content increased, compressive strength of the sample increased. Iwan Rustendi [31] employed waste iron sand and bottom ash as alternatives for concrete aggregate and discovered that these materials are a suitable replacement for fine aggregate in the production of concrete with a compressive strength of f'c $20 \mathrm{Mpa}$ at an average age of 28 days. Tuan Anh Nguyen [32] Reinforcing soft ground with fly ash-soil piles, the authors calculated the soft ground reinforcement under the roadbed using a hypothetical pile scenario. This research would examine the viability of making tiles out of waste PET bottles from municipal solid waste rather than cement. This research is entirely focused on designing and producing reliable tiles with better strength and flame resistance using recycled PET bottles, river sand, and fly ash.

\section{Materials and Methods}

\subsection{Materials}

The apparatus used in the experiment are as follows: metal mold, gas cylinder, burner, measuring scale, measuring bowl, lubricating oil, plier, metal bowl, screwdriver, brush, fire lighter, stirrer, and protective wears such as hand gloves, nose masks, boots, eyes shields, etc. The shredded plastic bottle wastes used in this study were obtained from a waste Resource Management 
company at 14000 Bukit Mertajam. While the river sand and the fly ash used were supplied to the School of Housing Building and Planning Resource Laboratory. Table 1 and Figures 1 - 3 below showed the chemical composition of the fly ash used, bags of shredded PET waste a sample of river sand, and fly ash respectively. Different chemical reagents of the technical grade like Hydrochloric acid $(\mathrm{HCl})$, Nitric acid $\left(\mathrm{HNO}_{3}\right)$, Sodium hydroxide $(\mathrm{NaOH})$, Sodium carbonate $\left(\mathrm{Na}_{2} \mathrm{CO}_{3}\right)$, Acetone, Acetic acid, Benzene, and Sodium chloride $(\mathrm{NaCl})$ necessary for determining the chemical tolerance of composite tiles were supplied by the School of Housing, Building, and Planning Resource Laboratory.

Table 1. Chemical composition of Fly Ash used.

\begin{tabular}{|cc|}
\hline Composition & Mass percentage \\
\hline $\mathrm{SiO}_{2}$ & 58.6 \\
$\mathrm{Al}_{2} \mathrm{O}_{3}$ & 24.01 \\
$\mathrm{Fe}_{2} \mathrm{O}_{3}$ & 6.35 \\
$\mathrm{CaO}$ & 4.28 \\
$\mathrm{MgO}$ & 1.74 \\
$\mathrm{~K}_{2} \mathrm{O}$ & 2.46 \\
$\mathrm{TiO}_{2}$ & 0.85 \\
$\mathrm{Na}_{2} \mathrm{O}$ & 1.71 \\
\hline
\end{tabular}

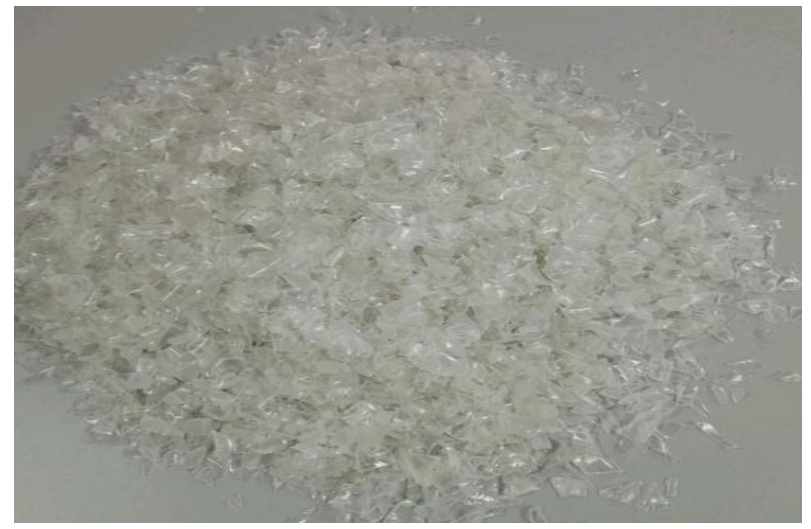

Figure 1. PET Wastes Sample

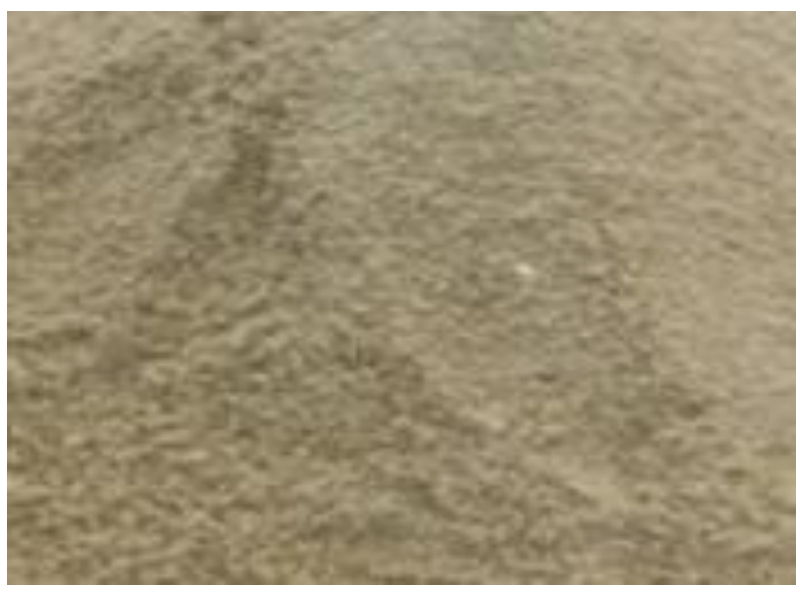

Figure 2. River Sand Sample

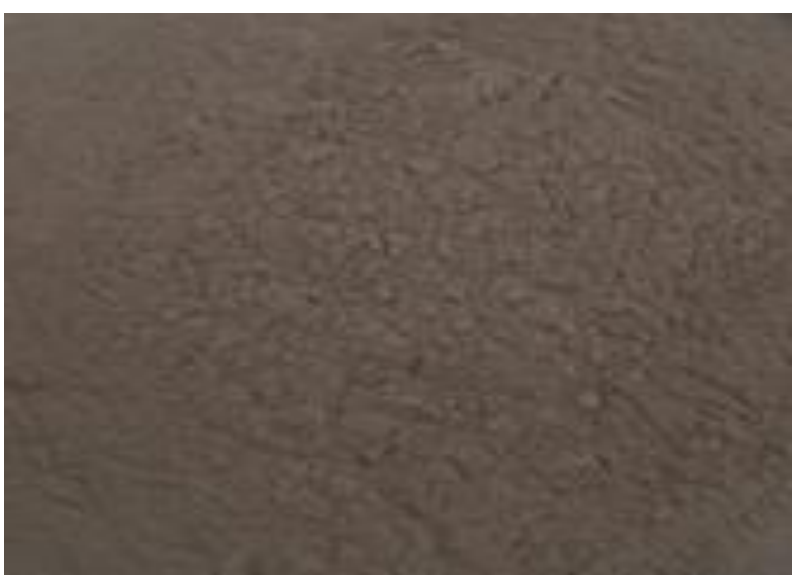

Figure 3. Sample of Fly ash

\subsection{Method}

The shredded PET wastes were heated inside the aluminum pot at a temperature of $230^{\circ} \mathrm{C}$ before adding the fine river sand into the melted plastic wastes according to the given composition in Table 2. The mixture was homogenized and poured into a $5-\mathrm{cm}$ thick iron mold that has been lubricated with engine oil for easy removal, and the edge of the mold was banged continuously for few minutes for proper compassion. After one hour, the samples were de-molded, cooled, and cured under ambient temperature for forty-eight hours before testing. Figure. 4 shows the samples of plastic tile produced. 


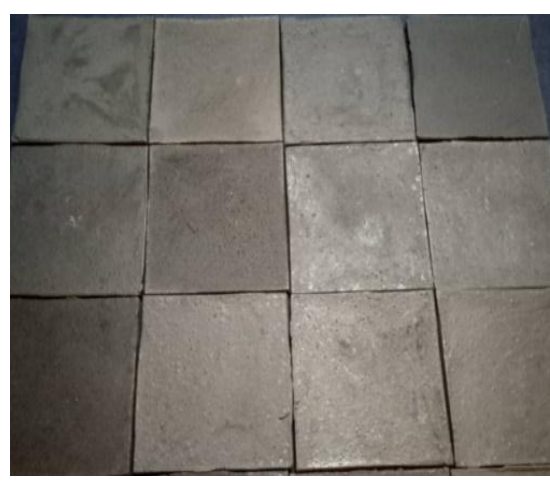

(a)

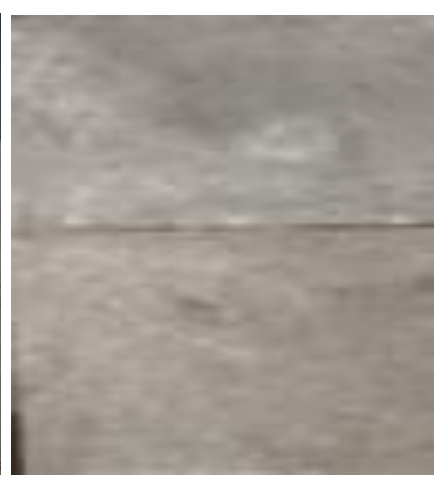

(b)

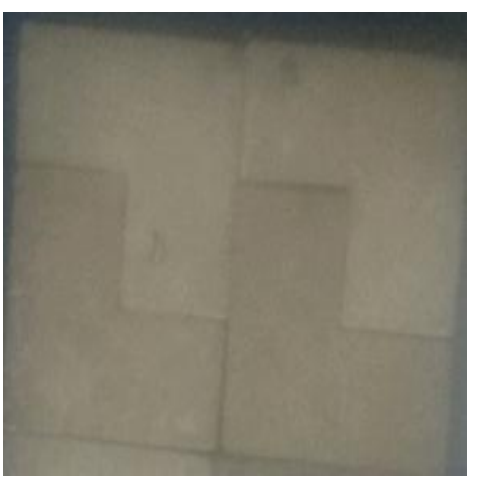

(c)

Figure 4. Samples of Plastic tiles

Table 2. Different contents of PET waste, Fly ash and sand aggregate used in this study

\begin{tabular}{cccc}
\hline Sample & $\begin{array}{c}\text { PET waste content } \\
(\text { wt. \%) }\end{array}$ & $\begin{array}{c}\text { Fly ash } \\
(\text { wt. \%) }\end{array}$ & $\begin{array}{c}\text { Sand } \\
(\text { wt. \%) }\end{array}$ \\
\hline PFST1 & 30 & 35 & 35 \\
PFST2 & 50 & 25 & 25 \\
PFST3 & 70 & 15 & 15 \\
PFST4 & 90 & 5 & 10 \\
PT & 100 & 0 & 0 \\
\hline
\end{tabular}

\subsection{Characterization}

The compressive strength of the composite tiles was measured with an Instron Universal Testing Machine (UTM 5967) at a crosshead speed of $5 \mathrm{~mm} / \mathrm{min}$ in accordance with ASTM D638. Samples with a gauge length of $50 \mathrm{~mm}$, a width of $50 \mathrm{~mm}$, and a thickness of 50 $\mathrm{mm}$ was formed to test the tensile strength. The density of the various composite tiles was determined. A flammability test in accordance with the ASTM D635 technique was performed on the rate of burning. Composite tiles made from recycled plastic were cut into $100 \mathrm{~mm}$ x $25 \mathrm{~mm}$ x $10 \mathrm{~mm}$ bar-shaped test samples. Each composite tile had at least three specimens, with an average burning rate recorded in millimeters per minute. In accordance with ASTM D543-14, the chemical tolerance of the composite tiles to the various chemical solutions was assessed. Samples of regular dimensions were individually cut and weighed from the plastic tiles. The samples were then soaked for seven days in various chemical reagents and the weight and dimensional changes were evaluated. The ASTM D570 standard was used to calculate the relative water absorption rate of these plastic tiles after immersion in them for a defined time period. All experiments were conducted at room temperature.

\section{Result and Discussions}

\subsection{Physical Properties}

\subsubsection{Sand Particle Size Distribution Test Results:}

The aggregate gradation of fine sand was evaluated using sieve analysis. Figure 5 and Table 3 proved that the sample sand is properly graded. Coefficient of uniformity, 0.2 to 0.6 values of Coefficient of gradation, and Fineness Modulus of 1.93 were obtained, which demonstrates that the aggregate is well-graded and fit for construction operations. The sample is graded in accordance with [24].

Table 3. Sand Particle size Distribution; Weight of Dry Sample (g):500.0

\begin{tabular}{|c|c|c|c|c|}
\hline $\begin{array}{l}\text { Sieve } \\
\text { Number }\end{array}$ & $\begin{array}{l}\text { Diameter } \\
(\mathrm{mm})\end{array}$ & $\begin{array}{l}\text { Soil Retained } \\
\text { (g) }\end{array}$ & $\begin{array}{c}\text { Soil } \\
\text { Retained } \\
(\%)\end{array}$ & $\begin{array}{c}\text { Soil } \\
\text { Passing } \\
(\%)\end{array}$ \\
\hline $5.00 \mathrm{~mm}$ & 5 & 0.00 & 0.00 & 100.0 \\
\hline $2.36 \mathrm{~mm}$ & 2.36 & 1.00 & 0.20 & 99.8 \\
\hline $1.18 \mathrm{~mm}$ & 1.18 & 23.00 & 4.70 & 95.1 \\
\hline $600 \mu \mathrm{m}$ & 0.6 & 113.00 & 23.40 & 71.7 \\
\hline $300 \mu \mathrm{m}$ & 0.3 & 191.00 & 39.60 & 32.1 \\
\hline $150 \mu \mathrm{m}$ & 0.15 & 114.00 & 23.60 & 8.5 \\
\hline \multirow[t]{2}{*}{ Pan } & & 41.00 & 8.50 & 0.0 \\
\hline & TOTAL: & 483.00 & & \\
\hline
\end{tabular}

The Fineness Modulus is 1.93 


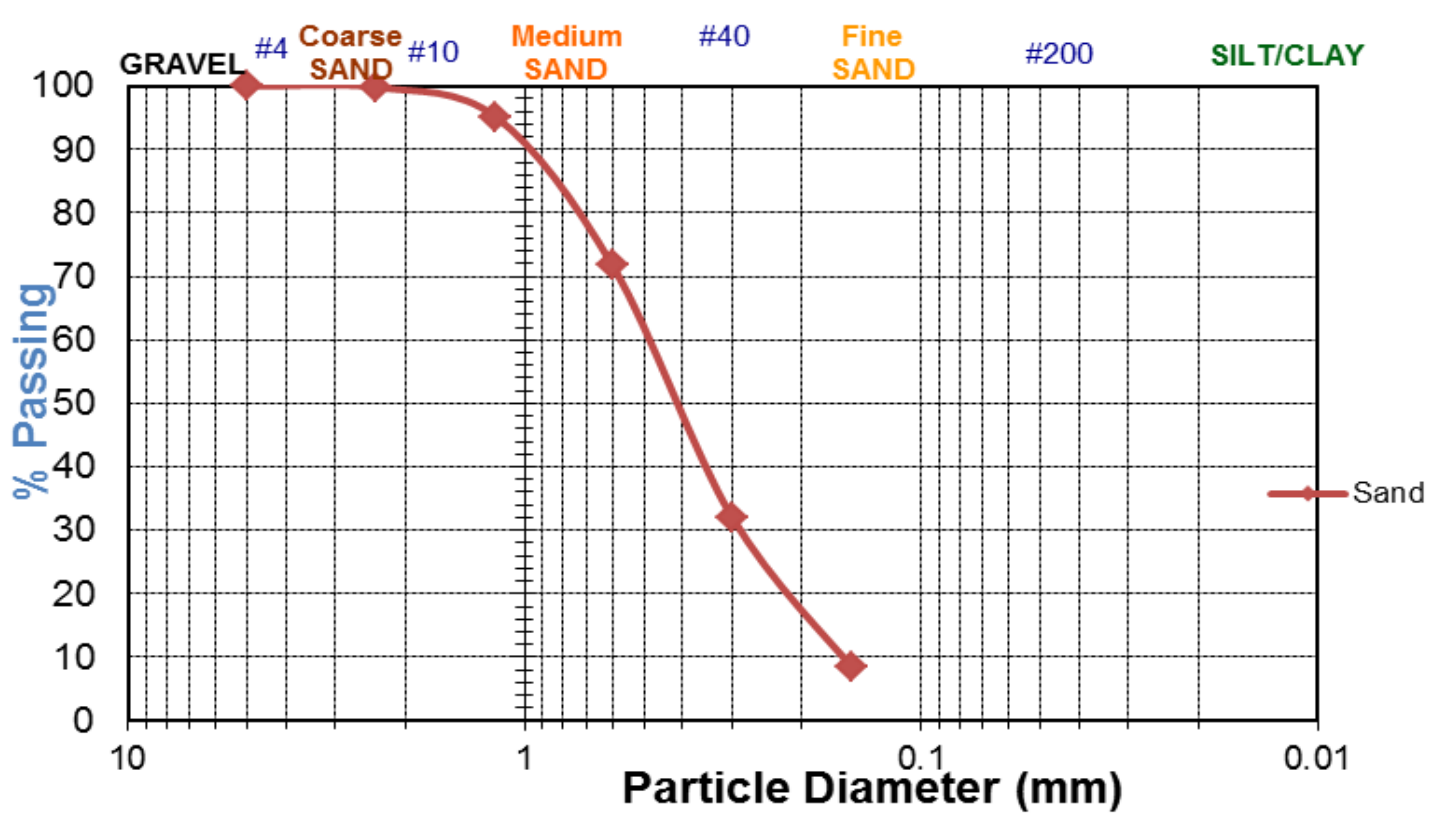

Figure 5. Particle size distribution of river sand

Table 4. Determination of Relative Density and Water Absorption of Sand Aggregate

\begin{tabular}{|c|c|c|c|c|c|c|c|}
\hline $\begin{array}{l}\text { TEST } \\
\text { NO: }\end{array}$ & $A(g)$ & B (g) & $C(g)$ & $\mathrm{D}(\mathrm{g})$ & $\begin{array}{l}\text { Relative Density } \\
\text { (Oven-Dried Basis) } \\
\frac{\boldsymbol{D}}{\mathbf{A - ( B - C )}}\end{array}$ & $\begin{array}{l}\text { Relative Density } \\
\text { (Saturated } \\
\text { Surface Dried) } \\
\frac{\text { A }}{\mathbf{A - ( B - C )}}\end{array}$ & $\begin{array}{c}\text { Water } \\
\text { Absorption \% of } \\
\text { Dry Mass } \\
\frac{\mathbf{1 0 0}(\boldsymbol{A}-\boldsymbol{D})}{\boldsymbol{D}}\end{array}$ \\
\hline 1 & 471 & 1,801 & 1,540 & 471 & 2.24 & 2.24 & 0 \\
\hline 2 & 498 & $1,819.3$ & $1,508.1$ & 497 & 2.66 & 2.67 & 0.20 \\
\hline 3 & 497 & $1,822.2$ & $1,506.6$ & 497 & 2.74 & 2.24 & 0 \\
\hline \multicolumn{5}{|c|}{ AVERAGE } & 2.55 & 2.38 & 0.07 \\
\hline
\end{tabular}

\subsubsection{Relative Density and Water Absorption of Sand Aggregate}

The result of relative density and water absorption of the sand was determined by weighing $500 \mathrm{~g}$ of sample sand and soak in water for 24 hours; and after poured inside a conical flask filled up with water and weigh, the sand was later sieved and sun-dried and weigh at surfaced dried. It was taken back to the oven to dry for another 24hour. The average relative density of 2.38 and $0.07 \%$ water absorption was obtained from the test conducted on the used river sand as shown in Table 4. This falls within the fine aggregates range described by [29]. Natural aggregates have a relative density that ranges between 2.4 and 2.9, according to Kosmatka et al. [25].

Where,

The mass of the Saturated Surface Dry sample in the air is denoted by $\mathrm{A}$.
B denotes the mass of the water-filled cylinder containing the sample.

$\mathrm{D}$ is the mass of the oven-dried sample in the air.

$\mathrm{C}$ is the mass of the Cylinder filled with water only

\subsubsection{Porosity}

The quantity of void space in a substance is measured by porosity, also known as a void fraction. Figure 6 and Table 5 shows the highest $\%$ porosity for the PET composite tiles was that of $30 \%$ PET $(2.83 \%)$ and the lowest $\%$ porosity was that of $90 \%$ PET $(0.11 \%)$. The percentage porosity of the composite tiles steadily decreased to $90 \%$ PET, of which all fell within $2 \%$ the standard range [Bamigboye et al. [6]. This implies that the porosity value of the PET tiles decreases with increasing PET content except for $100 \%$ PET tile. 
Table 5. Density, Compressive strength, Porosity and Flammability resistance (Linear burning rate) of the PET composite tiles of different PET, fly ash, and sand contents

\begin{tabular}{ccccc}
\hline Sample & $\begin{array}{c}\text { Linear } \\
\text { burning } \\
\text { rate } \\
(\mathbf{m m} / \mathbf{m i n})\end{array}$ & $\begin{array}{c}\text { Density } \\
\left(\mathbf{K g} / \mathbf{m}^{\mathbf{3}}\right)\end{array}$ & $\begin{array}{c}\text { Compressive } \\
\text { strength } \\
(\mathbf{M P a})\end{array}$ & $\begin{array}{c}\text { Porosity } \\
(\mathbf{\%})\end{array}$ \\
\hline PFST1 & 7.68 & 1764.8 & 11.10 & 2.83 \\
PFST2 & 9.80 & 1534.4 & 10.02 & 1.30 \\
PFST3 & 14.21 & 1301.6 & 7.11 & 0.89 \\
PFST4 & 16.91 & 1082.4 & 2.77 & 0.11 \\
PT & 21.20 & 1070.2 & 0.01 & 1.1 \\
\hline
\end{tabular}

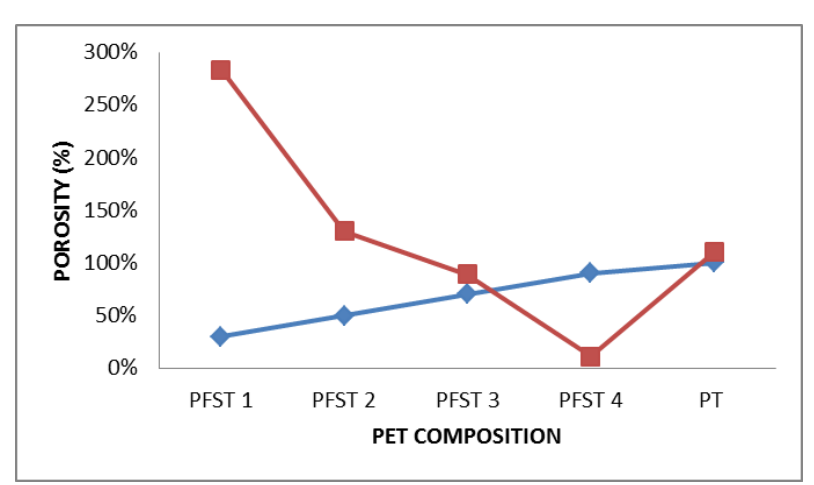

Figure 6. Porosity of sample

\subsection{Mechanical Properties}

\subsubsection{Density}

The density of the PET wall tile was determined. The result showed PFST1, PFST2, PFST3, PFST4, and PT5 are 1764.8, 1534.4, 1301.6, 1082.4, and $1070.2 \mathrm{~kg} / \mathrm{m}^{3}$ respectively, the produced composite tiles with $100 \%$ PET had the least density $\left(1070.2 \mathrm{~kg} / \mathrm{m}^{3}\right)$ while those produced with $30 \%$ PET content had the highest density $\left(1764.8 \mathrm{~kg} / \mathrm{m}^{3}\right)$ as shown in Figure.7. Observably, increases in the PET content means a decrease in the density of the composite tile. Notably, it is previously indicated that the increase in PET content has reduced the density of the resulting composites [26, 27].

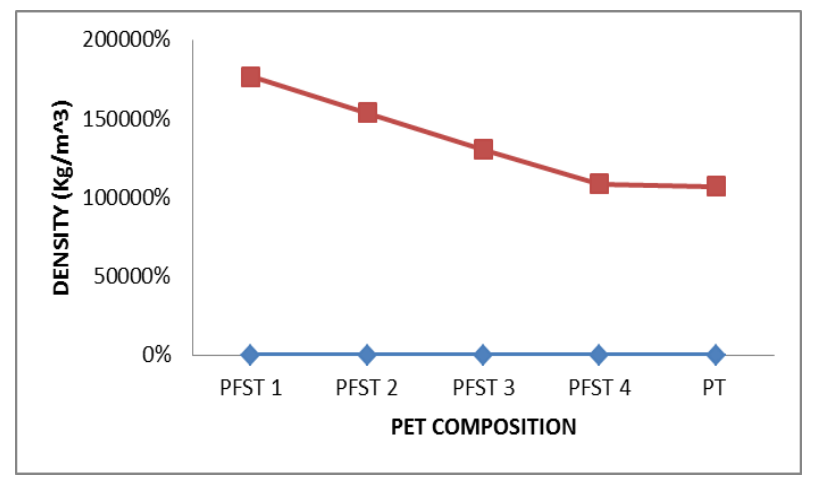

Figure 7. Average Density of the sample

\subsubsection{Compressive Strength}

The highest compressive values for the PET composites were that of $30 \%$ PET (11.10 MPa), while the least strength value was $100 \%$ PET (1070.2 MPa). This value was higher than the compressive strength of other conventional tiles. The compressive strength values of 11.10, 10. 02, 7.11, 2.77, and 0.012 MPa for PFST1, PFST2, PFST3, PFST4, and PT respectively, increases gradually with an increase in sand and fly ash content but decreases with an increase in PET content (see figure 8). The results show that the increase in the PET waste content means a reduction of the compressive strength of the composite [26-28].

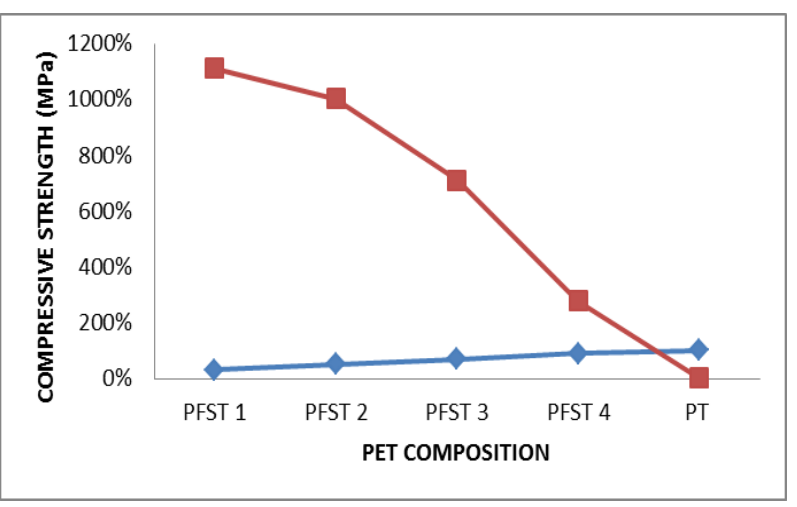

Figure 8. Average compressive strength of the samples

\subsection{Flammability}

The given tiles samples were cut into $100 \mathrm{~mm}$ bars and their rate of linear burning was measured. ASTM D635 was used to determine rates of linear burning of the three composite sample specimens, wherein $100 \mathrm{~mm}$ sample bars sustained at one end were burned for about 30 seconds each with specified burning from the other end, and timed to get to the $100 \mathrm{~mm}$ mark from the lit the end was recorded, as illustrated in Figure 9. To determine the linear burning rate of the sample $(\mathrm{V})$, the average burning rate of three specimens was used. The linear burning rate for each sample, or the time required to reach $100 \mathrm{~mm}$ from the flame front, can be computed using the equation:

$$
\mathrm{V}=60 \mathrm{~L} / \mathrm{T} \text {. }
$$

Where $\mathrm{L}$ is the burned length in millimeters and $\mathrm{T}$ is the period in minutes.

The linear burning rate of waste 100 percent plastic tile was found to be $21.2 \mathrm{~mm} / \mathrm{min}$, which is consistent with published figures. Furthermore, the addition of river sand and fly ash to waste plastic paste in various weight percentage loadings reduces the rate of burning in composite tiles by $16.91,14.21,9.80$, and 7.68 $\mathrm{mm} /$ minutes, as shown in Fig. 9. The results of the experiment revealed that the combination of river sand and fly ash aggregates in PET paste provided some form of barrier, causing the composite tiles to burn slower than the pure 100 percent PET plastic tile. This is owing to the presence of sand and fly ash, which are non-conducting ceramics materials. Ceramics materials such as $\mathrm{SiO}_{2}, \mathrm{Al}_{2} \mathrm{O}_{3}$ 
and $\mathrm{TiO}_{2}$ are thermally stable up to $2000{ }^{\circ} \mathrm{C}$. These metal oxides inhibit polymer carbonization, resulting in a more durable and effective char layer that serves as a barrier between surface burning and undecomposed material. This minimizes heat and fuel transfer to the burning front [Li et al., 2011]. As a result, as sand and fly ash content increases, the linear burning rate falls [R. Dhawan et al. 2019].

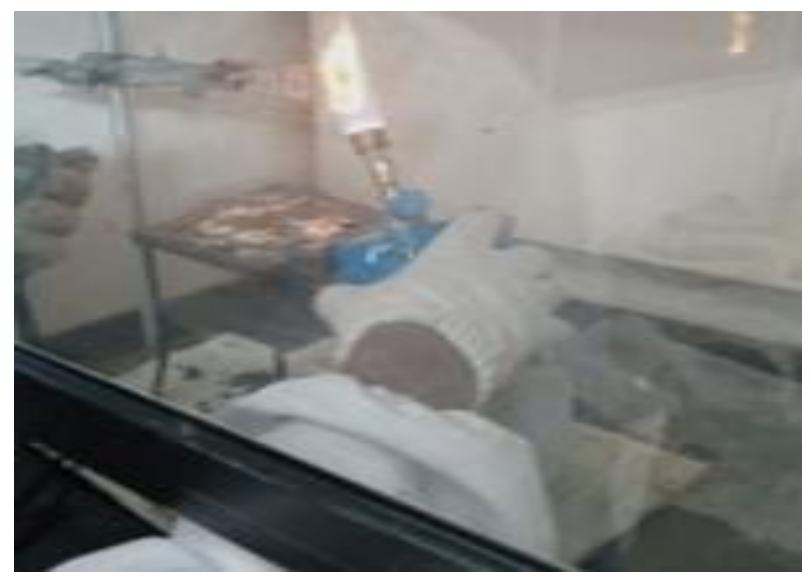

(a)

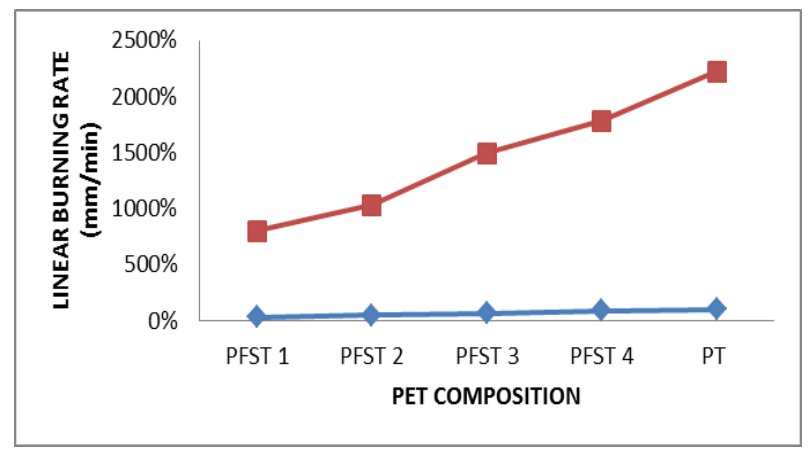

(b)

Figure 9. (a) Mounted specimen on a stand with a Bunsen burner burning the sample up to the $100 \mathrm{~mm}$ mark; (b) linear burning rate ( $\mathrm{mm} / \mathrm{minute})$.

\subsubsection{Chemical resistance}

Chemical resistance testing on the samples was carried out according to ASTM D543-14 guidelines. The samples were prepared with length $=20 \mathrm{~mm}$, width $=20 \mathrm{~mm}$, and thickness $=10 \mathrm{~mm}$, then weighed and immersed in various chemicals Hydrochloric acid (HCL), Sodium chloride $(\mathrm{NaCl})$, Sodium carbonate $\left(\mathrm{Na}_{2} \mathrm{CO}_{3}\right)$, Acetone, Benzene, Acetic Acid, and Carbon Tetrachloride) $\left(\mathrm{CCl}_{4}\right)$. The experiment was carried out at room temperature for 168 hours, as shown in Figure 10. Following the soaking time, the samples were removed, rinsed with distilled water, and air-dried before measuring the weight and dimensions of the soaked samples and comparing them to the weight and size of the neon-soaked samples. Comparative findings revealed no significant changes in sample weights or measurements after 7 days of soaking in different chemicals; this finding is consistent with Dhawan et al. [28].

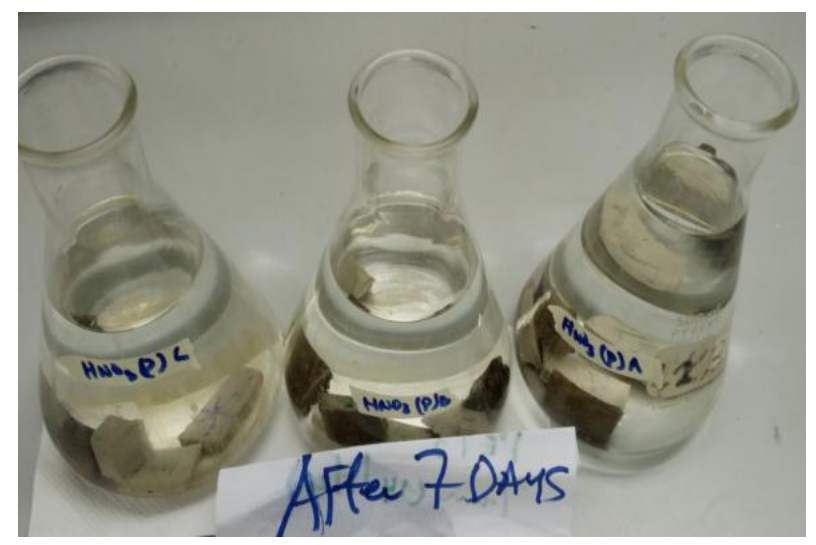

Figure 10. Specimen samples soaked in different chemicals for 7 days

\section{Conclusions}

Based on the experimental results, the following conclusions can be drawn:

- The average densities of the tile specimen with the lowest recorded density were at $100 \%$ PET (1070.2 $\left.\mathrm{kg} / \mathrm{m}^{3}\right)$ and the highest for PET was $30 \%$ PET (1764.8 $\mathrm{kg} / \mathrm{m}^{3}$ ). The densities rise steadily with an increase in sand and fly ash content but decrease with a percentage increase in PET waste when compared with the composite tiles.

- Percentage porosity decrease when the amount of PET waste increases in the composite tile between $30 \%$ to $90 \%$ PET but changes at $100 \%$ PET as a binder in full replacement of cement. Percentage porosity decreased from $2.83 \%$ to $0.58 \%$

- The compressive strength and flexural strength of the composite tiles decreased with an increase in PET waste as a binder. The compressive strength decreased from 11.10 MPa (30\%PET) to $0.012 \mathrm{MPa}$ (100\%PET). The increase in compressive strength is the product of a good distribution of aggregates in polymer matrices. As a result, the sand and fly ash particles will keep the polymer chains together to enhance their deformation resistance, resulting in an increase in compressive strength.

- The flammability resistance of the composite tiles decreases with an increase in PET waste but increases with an increase in sand and fly ash content. The linear burning rate increased from $7.76 \mathrm{~mm} / \mathrm{min}$ to $21.20 \mathrm{~mm} / \mathrm{min}$. The results of the experiment revealed that the addition of river sand and fly ash to composite tiles provided some form of barrier, causing the tiles to burn slower than pure $100 \%$ PET plastic tiles. The sand and fly ash particles reduce polymer carbonization, resulting in a more durable and effective char layer that serves as a barrier 
between the burning surface and un-decomposed material. Therefore, the linear burning rate decreases by increasing the sand and fly ash content.

- The tolerance of composite tiles in various chemical solutions of hydrochloric acid $(\mathrm{HCl})$, sodium hydroxide $(\mathrm{NaOH})$, sodium chloride $(\mathrm{NaCl})$, Sodium Carbonate $\left(\mathrm{Na}_{2} \mathrm{CO}_{3}\right)$, Acetic acid, Acetone, Benzene, and Nitic Acid $\left(\mathrm{HNO}_{3}\right)$ soaked at room temperature for 168 hours or 7 days observations showed no major changes in weight or dimensions.

According to the findings of this report, PET waste bottles can be used to make long-lasting, high-strength, reduced flammability, low-water-absorption, and eco-friendly tiles for both residential and commercial applications. This possibility of producing tiles from polyethylene terephthalate (PET) waste, sand, and fly ash would not only reduce the cost of construction materials but would also serve as a waste diversion to reduce environmental pollution generated by plastic waste disposal.

\section{Conflicts of Interest}

No conflicts of interest.

\section{Acknowledgments}

The Authors appreciate the Dean of School of Housing, Building, and Planning Universiti of Sains Malaysia for providing materials needed by this research and the Federal Government of Nigeria for TETFUND granted to the author.

\section{REFERENCES}

[1] P. O. Awoyera, A. Adesina. "Plastic wastes to construction products: Status, limitations and future perspective" Case Studies in Construction Materials vol. 12 (2020) e00330, http://dx.doi.org/10.1016/j.cscm.2020.e00330.

[2] Jambeck, B. Denise, A. L. Brooks, T. Friend. K. J. Fabres, Y. Beaudoin. A. Bamba. J. Fancis, A. J. Ribbink, T. Baleta, H. Bouwman, J. Knox, C. Wilcox. "Challenges and emerging solution to the land-based plastic waste issue in Africa", Mar. Policy 96 pp 256-263, 2018, doi: http://dx.doi.org/10.1016/j. marpol.2017.10.041.

[3] P. Singh, V. P. Sharma." Integrated plastic waste management: environmental and improved health approaches", Procedia Envirn. Sci. 35 pp 692-700, 2016 doi: http://dx.doi.org/10.1016/j.proenv.2016.07.068.

[4] R. Saxena. T. Gupta, R. K. Sharma, S. Chaudhary, And A. Jain. "Assessment of mechanical and durability properties of concrete containing PET waste". Scientia Iranica. Transactions A: Civil Engineering 27, pp 1-9, 2020.

\section{DOI:10.24200/sci.2018.20334}

[5] A.L. Brooks, S. Wang, J.R. Jambeck, "The Chinese import ban and its impact on global plastic waste trade", Sci. Adv. 4 (6) (2018) eaat0131

[6] Bamigboye G. O., Adedeji A.A., Olukanni D. O., Jolayemi K. J., "Reliabilty of gravel in place of granite in concrete production". Journal of Engineering and Applied Sciences 12 (20): pp 5121-5128, 2017.

[7] Simanshu, P. Pandey, S. G., Wankhade, S. A. "Waste plastic bottle as construction material". International Advanced Research Journal in Science, Engineering and Technology (IARJSET), pp 1-6. 2017.

[8] Saoula, S, Haddadi, S., \& At-moktar, K.” Performances me'caniques des be'tons bitumineux modifies a' based' additifs polymers". In: Proceeding of 1 st international conference on sustainable built environment infrastructures in developing countries, pp 12-14, 2009.

[9] Abraham, D. R., Anu, J., Arakkal, J., Binuraj, P. R., \& Jithin, S. "Development of coir-fibre cement composite roofing tiles". International Conference on Emerging Trends in Engineering, Science and Technology Chennai, India: Elsevier. pp. 169-178, 2016.

[10] Spencer, C. N. "Utilization of ethyl cellulose polymer and waste materials for roofing tile production". 7th International Conference on Environment and Industrial Innovation, pp. 1-8, 2017. IOP Publishing Ltd.

[11] Kolawole F. O., Adeniji S. A., Idowu A. T., Owoseni T. A., Ngasoh O. F., \& Soboyejo W.O. "Corrugated laterite based ceramic roof tile stabilized with cement". International Journal of Engineering and Technology, 145-149, 2014.

[12] Otuoze H. S., Amartey Y. D., Sada B. H., Ahmed H. A., Sanni M. I., \& Suleiman M. A. "Characterization of sugar cane bagasse ash and Ordinary Portland Cement Blends in Concrete", in: Laryea S., Agyepong S.A., Leiringer R., Hughes W. (Eds). 4th West African Built Environment Research (WABER) Conference pp. 1231-1237, 2012. Abuja, Nigeria: West Africa Built Environment Research (WABER) Conference.

[13] Ramaraj, A. P., \& Nagammal, A. N. "Exploring the current practices of post-consumer PET bottles and the innovative applications as a sustainable building material". 30th International Plea Conference pp. 16-18, 2014. Ahmedabad: Cept University Press.

[14] Velumani P., \& Karthik S. G., "Development of eco-friendly pressed roof tiles: A prologue study". International journal of scientific and engineering research, 8 (12), 2030- 2033, 2017.

[15] Mehdi S., Djamel B., Abdelouahed K., \& Mohamed I. H., "The possibility of making a composite material from waste plastic". International Conference on Technologies and Materials for Renewable Energy, and Environment. Beirut lebanon: Elsevier, pp 163-169, 2017.

[16] Agbede, O., Tersoo, A., Tiza, M., \& Terry, U. "Production of concrete roofing tiles using rice husk ash (rha) in partial replacement of cement". International Research Journal of Engineering and Technology (IRJET), pp. 2678-2689, 2016.

[17] Zerdi, T. A., Yusuf, M., Minhajuddin, M., Waseem, M. F., and Zerdi, M. N. "partial replacement of coarse aggregates 
with virgin plastic granulud (HDPE) in concrete mix" Indian Journal of Applied Research, 6(5), pp. 655- 657, 2016.

[18] Fadlalla, N. "Management of PET plastic bottles waste through recycling in Khartoum State". Sudan: Sudan Academy of Science Engineering Research and Industrial Technology Council, 2010.

[19] I. I Akinwumi, A. H. Domo-spiff, A.Salami,. "Case Studies Construction Materials Marine plastic pollution and affordable housing challenge: shredded waste plastic stabilized soil for producing compressed earth bricks", Case Stud. Constr, Mater. $11 \quad$ (2019)e00241, doi: http://dx.doi.org/10.1016/j.cscm.2019.e00241.

[20] A. Kumi-Larbi, D. Yunana, P. Kamsoulounm, M. Webster, D. C. Wilson, C. Cheeseman. "Recycling waste plastics in developing contries: use of low-density polyethylene water sachets to form plastic bonded sand blocks". Waste Manag. 80 pp 112-118, 2018 doi: http://dx.doi.org/10.1016/j.wasman.2018.09.003

[21] Y. Yang, R. Boom, B. Irion, D.J. Van Heerden, P. Kuiper, H. de Wit. "Recycling of composite materials", Chem.Eng. Process. Process Intensif. 51 53-68, 2012. DOI http://dx.doi.org/10.1016/j.cep.2011.09.007.

[22] AL-Hadithi, A.I and Hilal, N.N. "The possibility of enhancing some properties of self-compacting concrete by adding waste plastic fibres", Journal of Building Engineering, 8A, pp. 20-28, 2016. DOI: http://dx,doi.org/10.1016/j.jobe.2016.06.011.

[23] Borg, R. P., Baldacchino, O., and Ferrara, L. "Early age performance and mechanical characteristics of recycled PET fiber reinforced concrete", Construction and Building Materials, 108 pp. 29-47, 2016.

[24] American Society for Testing and Materials (ASTM C136). "Standard Test Method for Sieve Analysis of Fine and Coarse Aggregates". West Conshohocken, PA, USA. 2001.
[25] Kosmatka, S. H., Kerkhoff B., \& Panarese W. C., "Design and control of concrete mixtures", 4th Edition., Portland Cement Association, California. 2003.

[26] Zerdi, T. A., Yusuf, M., Minhajuddin, M., Waseem, M. F., and Zerdi, M. N. "partial replacement of coarse aggregates with virgin plastic granulud (HDPE) in concrete mix" Indian Journal of Applied Research, 6(5), pp. 655- 657, 2016.

[27] Usman, M., Javaid, A., and Panchal, S. "Feasibility of waste polythene bags in concrete", International Journal of Engineering Trend and Technology (IJETT), 23(6), pp. 317- 319, 2015.

[28] Ridham Dhawan, Brij Mohan Singh Bisht, Rajeev Kumar, Saroj Kumari, S. K. Dhawan "Recycling of plastic waste into tiles with reduced flammability and improved tensile strength", Process Safety and Environmental Protection 124 (2019) 299-307Advanced Engineering, 2(6), pp. 42-46.

[29] American Society for Testing and Materials (ASTM C128). "Standard Test Method for Density, Relative Density (Specific Gravity), and Absorption of Fine Aggregate". West Conshohocken, PA, USA, 2001

[30] British Standard (BS EN ISO 604). "Plastics-Determination of compressive properties". British Standard, United Kingdom, 1999.

[31] Iwan Rustendi, Eddy Poerwodihardjo, Citra Pradipta Hudoy "Utilization of Iron Sand Waste and Bottom Ash as Alternate Concrete-making Materials" Civil Engineering and Architecture 8(4): 549-556, 2020. DOI: 10.13189/cea.2020.080419.

[32] Tuan Anh Nguyen, Dat Thanh Nguyen, Tung Thanh Pham3, Linh Truong Chau "Study on Using Fly Ash for Fly Ash Soil Piles in Reinforcing Soft Ground" Civil Engineering and Architecture 8(5): 1074-1085, 2020. DOI: 10.13189/cea.2020.080534. 